\title{
Livelihood Change and Household Strategies: Social Displacement of the Upper Class in Dhading
}

\author{
Youba Raj Luintel
}

\begin{abstract}
This article examines livelihoods transition among agrarian households in a cluster of villages adjacent to Kathmandu in a post-Neoliberal context. It specifically looks at the way these households respond to capitalist expansion in Nepal's agrarian rural setting privileged to draw cash earnings. Looked at from the quest of longer term social change, this article identifies a great deal of similarity in household responses along class lines, and thus, concludes that household strategies broadly embrace class-specific behaviour. In identifying patterns of household response, this article also argues that class-differentiated analysis of household response can potentially illuminate social science understanding of the way capitalism penetrates into the countryside and brings social differentiation. Finally, this article demonstrates that social differentiation of agrarian households in rural Nepal is a mechanism of siphoning off of the rural surplus somewhere else (in this research context Kathmandu)-a mechanism widely attributed for an uneven development and underdevelopment of countryside Nepal.
\end{abstract}

Keywords: Capitalism, class, social change, social divergence, underdevelopment 


\section{Introduction}

This article aims to answer a couple of specific research questions: how do households reposition themselves amidst the increasing opportunities and constraints the capitalist market entails? ${ }^{1}$ In particular, how do upper class households reposition themselves? Do household responses exhibit any pattern that helps us understand long term social change? If so, what theoretical significance can such patterns offer in the wider political economic context of shifting class formations? It demonstrates that the upper class households in Mahesh $\mathrm{Khola}^{2}{ }^{2}$ the research site of the present research, are currently in a dilemma regarding hiring wage labour or keeping their land fallow, neither of which is rewarding to them. This dilemma stems from the increasing priority bestowed on trade, education and employment which, in the long run, often results in dual residence or even (self) displacement.

Two issues emerge as vitally important in relation to the focus of the present article. First, in identifying similarities in the range of strategies that households adopt, one can conclude that household strategies broadly represent class-specific behaviour. Second, in identifying some patterns of household response as a manifestation of local response to capitalist encroachment class-differentiated analysis of household response can potentially illustrate how capitalism penetrates into the countryside and brings social divergence.

\section{Conceptual Underpinning of the Notion of Household Strategy}

There has been a recent upsurge in the study of household coping strategy in different - such as post-disaster, post-conflict circumstances. This article looks at household strategy adopted by

1. This article is a condensed version of a chapter of the $\mathrm{PhD}$ thesis that I submitted to Newcastle University, UK in 2011.

2. Mahesh Khola, a pseudo-name used to conceal the actual identification of the location, is the site of my doctoral research. The area is located immediately outside Kathmandu Valley on its west and encompasses the surroundings consisting of about 42 settlements in or around an area conventionally known as "Dhunibesi" in Dhading district. The field research on which this article derives data was carried out in 2007. 


\section{8| Youba Raj Luintel}

upper class households in an agrarian community of Mahesh Khola, Dhading in the wider context of rapid expansion of capitalist market there.

Household strategies are defined as "the bundle of...responses" that they devise under a situation of "recurrent threats" and aim to "minimize risk" or ensure "longer-term livelihood security" (Davies, 1993 , p. 60). These mostly refer, however, to coping strategies in the short term and social adaptation (or what I would call household repositioning) in the longer term. Recently there has been an increase in social science interest in longer term household strategies (in the sense of adaptation to a new situation) in which outcomes of fundamental changes in livelihood systems are taken into account (Davies, 1993, p. 60). They mostly refer to strengthening household resilience to more structural vulnerabilities, such as market encroachment (see Davies, 1993, p. 62).

The notion of household strategy suffers from a number of ambiguities. One ambiguity relates to a proper distinction between what is "strategic" and what is not. Does every household always necessarily take rational decisions? What about the non-rational or irrational actions (Wallace, 2002) or unconscious strategies (Morgan, 1989)? What seems more important to me, therefore, is whether household actions or decisions were taken consciously, and whether that had been sufficiently discussed with family members, so that the decisions were owned by the members with whom it would have an impact.

The second ambiguity stems from the issue of vantage point: whose rationality do social scientists' count? It is argued that in most of the accounts of household strategies, "the views and explanations of social actors are rarely elicited" and rather "tautological reasoning" (that labels all household behaviour as "strategic") is drawn (Wolf 1997, p. 130). This point is well taken in this article. A third ambiguity of the notion of household strategy relates to its inability to distinguish several types of households. A household level analysis must recognise that household strategies exhibit a pattern based on demographic, occupational and economic similarities, hence it is also important to recognise what kind of household took what actions. It is in this context that I bring class analysis into the 
discussion of household strategy.

A final ambiguity relates to intra-household dynamics. Feminists argue that household strategies necessarily embody relationships of power, domination and subordination. Feminist critique such as this refers to the conflation of individual household members with the household itself, thus ignoring intra-household inequalities in household decision. Wolf argues that "for a household strategy to be created, a decision must be made (Wolf, 1997). Crow (1989) makes the point clear when he says the idea of strategy is not to build on the assumption of consensus within households, but to acknowledge that different strategies may stem from different household members, who may or may not be in conflict and that there is always a space for negotiation, an intra-household dynamic which Sen calls "cooperative conflict" (1990, p. 125). Therefore, to me, the feminist dispute with the household strategy approach is important as it sensitises us toward a range of asymmetries within households.

Having said this, I follow Warde (1990) and Wallace (1993), who argue that we can limit our research to looking at the outcomes of household activity, acknowledging that the intra-household bargaining and conflicts are taken into account. An analysis of the intra-household dynamics of household strategies has been postponed in this research also because it falls outside the purview of the present study. Accordingly, in what follows, I look for patterns, as reflected in the decisions made and actions taken by a group of privileged households.

\section{Findings and Discussion}

If the intra-class divergence of the working class is characterised by an increasing emphasis on nonfarm wage work (or labour migration), or alternatively, a shift to agricultural self-employment (through selfcultivation, renting-in, and perma), the upper class households have resorted to a quite different set of household strategies in Mahesh Khola. The upper class in Mahesh Khola is currently in a dilemma in regard to hiring wage labour to keep the land cultivated or leaving their land fallow because they themselves are increasingly turning to trade, education and employment. I make an argument that, in the 
long run, this has resulted in a practice of dual residence, and dual residence is the very process that has made possible siphoning of the surplus generated in Mahesh Khola to elsewhere. But before this, let me introduce some aspects of labour dynamics with regard to the working class households again, as background dynamics to the changing livelihoods options of the upper class.

\subsection{Broader dynamics of shortage of wage workers in Mahesh Khola-a preliminary note}

Intra-class divergence of the working class through two simultaneous processes of the shifting priority to urban and nonfarm wage work, and the pursuit of agricultural self-employment have skewed the supply of wage workers in Mahesh Khola. Although, the relative importance of farm wage has certainly declined, it is still an important part of livelihood pursuits for both the working class and their upper class counterparts - for different interest and benefits. While earning a wage from the locally available farm work opportunities is the clear the motive of the workers pursuing wage labour; ensuring timely and efficient cultivation and getting good harvests are the main motives of their upper class counterparts. Ram Rai, once a fulltime wage worker, later converted into petty trade and now a self-employed fulltime farmer sheds further light on this:

As the poor people, we continue doing wage work to earn some cash, at least for salt-and-oil [commodities of daily use], because we often don't have money at hand. Its not that everybody has started refusing offers of instant cash payment [in farm wage], but the priority is certainly on one's own cultivation now... One would do wage work only when his [or her] own cultivation is completed. No one will tolerate anymore any pressure to work for wages in this village.

-- Ram Rai, 55, one of the key-informants in Mahesh Khola

Ram's assertion manifests the changing priority of the working class households in Mahesh Khola - from wage work to agricultural self-employment and beyond. Partly it reflects their strengthened fallback position ${ }^{3}$ that enabled them to bargain with the landowners,

3. A term popularly used in gender studies, it indicates women's bargaining within patriarchal households. I use it here in a loose sense to denote 
upon whom they had been heavily dependent for money and (for access to) land, up until the late 1980s.

The household survey shows that, after mobilising family labour the sample households were still short of labour to accomplish their farm work (in parcels of one's own and rented-in land). Hence, they had to seek additional labour support, for which a total of 3,558 persons (other than one's own family members) were mobilised by 61 sample households together during the year 2006-07. Wage labourers occupied 43.1 percent, the rest was perma. The household survey also reveals that 17 of 61 sample households had one or more of their family members engaged in farm wage. ${ }^{4} \mathrm{~A}$ very broad estimation suggests that an average wage income of households participating in farm wage was Rs 8,292 in 2006-07, ${ }^{5}$ which accounted for 19.4 percent of their total household income (compared to 52 percent income from the entire agricultural production). It shows that although the relative importance of farm wage has declined, it still occupies one of the main income sources for the working class. With this background, in the following section I will focus on the dynamics of the upper class households.

\subsection{Upper class's challenge of keeping their land cultivated}

The reality in Mahesh Khola is that unless a household owns very good quality of land (preferably khet), having a large area of land alone does not guarantee a better income. Those who had large plots of land earlier would now find it challenging to keep them cultivated. And, the changing dynamics of livelihoods has shown that big landowners are not necessarily richer ones. While earlier they had the privilege of relying on attached labour, wage labour, and/or complementary (unpaid) labour, no one is entitled to any such privileges now. Now, the main challenge for them is to keep the land cultivated, to ensure a proper share of the harvest (depending upon

economic fallback position of poor households on which they will have to depend if the existing production and income avenues fail to support them. 4. This is one of the main criteria I used to distinguish the class position of households in Mahesh Khola. This figure, however, does not include circular movements to Kathmandu on a daily basis.

5. The market prices of commodities and services refer to 2007 actual market price. 


\section{2| Youba Raj Luintel}

negotiation with the tenant/cultivator), and to circumvent any claims for tenancy rights on the part of the latter. Many of the upper class households who have employment in Kathmandu would want to sell their land now because they cannot keep the land cultivated on their own. But the problem is there is not much demand in buying land, except along the main corridors of some newly constructed roads. This relates directly to the socio-economic contradictions evolving over the years in Mahesh Khola, which is that, despite some observable improvements in the levels of income, the working class households have not substantially improved their assets portfolio. As a result, they are still not in a position to make any substantial investment, such as purchasing land. This has added a clear discomfort to the upper class households because their estates and property are not being sold at a competitive price. Hence, they have no option but to keep the land cultivated, even if they are unwilling to do so. ${ }^{6}$ In such a case, households have one or all of the following options: (a) joining reciprocal labour exchange practice, such as perma, (b) allocating land for adhiya, or (c) renting it out (under thekka). Although both adhiya and thekka are still in vogue in Mahesh Khola, to varying degrees, the upper class households increasingly fear that they do not have a comparative advantage in either. In the section that follows I highlight their preferred livelihood options and where they perceive a better advantage.

What would the upper class households do when they manage to sell or rent-out all of their land in the village? My field investigation in Mahesh Khola shows that it brings a U- turn in their livelihoods. They are likely to leave the farm-based livelihood (and, the place of their origin) altogether in favour of a fairly nonfarm based livelihood. Byapar (trade) and jagir (employment in the formal sector) are the

6. This has resulted into underutilization of land in Mahesh Khola, which is a part of an emerging but larger national problem in contemporary Nepal. Leaving land fallow is culturally unacceptable in Nepali society. A household can afford neither to leave the land fallow (because of the public shame involved in this), nor can it effectively cultivate it. Although leaving land fallow is not evident in Mahesh Khola yet (because adhiya and thekka systems have contributed as a safety valve), the problem of land underutilization, however, has already been an issue. I could see patches of land, particularly the marginal ones, left fallow between seasons (particularly during winter). 
two major activities households such as these would eventually opt for. Nonfarm income refers to households' involvement in trade or entrepreneurship (to be explicit, tarkari byapar, i.e. vegetable trade, in Kathmandu). The term tarkari byapar includes a range of trading activities of varying scales, from street vending (selling fresh vegetables on the streets), pasale (having a rented outlet for the retail sale of vegetables) to a thok byapari (a wholesaler with an outlet in the Kalimati Fresh Vegetables Market).

Although households which are mainly engaged in wholesale vegetable trade remained largely out of the scope of the sampling frame of this research, as most of them had already left Mahesh Khola, I gathered additional information about them separately. But before I do so, let me make a brief discussion on data generated by household survey. With reference to the sample households, 11 out of the total 61 households had some sort of nonfarm income from Kathmandu, including seven from the petty trade of vegetables. The average contribution of nonfarm income (calculated as the average amount sent home on a monthly basis during the 12 months preceding the survey) to these 11 households was Rs 26,318. This exceeded an average contribution from farm production (Rs 19,185 in average) to each household. Hence, even a marginal engagement in trade enabled these households to accrue an income comparable to that of the main staple crops. It opens up many aspects of the structural changes through which the economy of Mahesh Khola is passing now. It is a reason for many households to put emphasis on the nonfarm sector, which directly relates to declining vegetable production, their low (or even declining) farm gate price, together with the escalating price of agricultural inputs, such as fertilisers. In what follows, I examine which section of the upper class is more likely to get urban employment and what its implications would be in relation to capitalist development in Mahesh Khola.

\subsection{Better education and caste connections as premiums to upper class}

During the 1980s, many of the upper class households in Mahesh Khola were fortunate to have been able to invest relatively better (than their working class counterparts) in their children's education. During this time vegetable production had just started and the working 


\section{4| Youba Raj Luintel}

class households were still struggling with the basic problems of survival; as a result investment in their children's education was still a luxury to them. However, the upper class households were already in a position to afford their children better education (even by sending them to Kathmandu). This fundamental gap between the two classes is now having longer term livelihood implications as the upper class households are now getting "very large premiums" from the earlier investments in their children's education, a situation also reported in India (Panini. 1996, p. 39). This is a phenomenon that has also been observed nationally in Nepal as reflected in the two NLSSs (CBS 2005; CBS 2006a; CBS, 2006b, DFID and WB 2006).

While a cohort of those children has already become adult and has gained relatively better paid jobs in the public sector (civil service, police, army, schools), children of the same generation from the working class households are either illiterate or poorly educated through the poorly funded public schools in the village. In addition, due to their lack of connection with the corridors of power and bureaucracy in Kathmandu, a result of their disadvantaged class (including caste-ethnic-occupational belongings), their chances of getting similar opportunities is fairly low. It is still true that in Nepal.

[p]olitical and economic power are [still to some extent] gained through patronage, nepotism, and ethnic connections... It is a country which is deeply segmented by language, cultural and ethnic differences...[; further] exaggerated by a dominant Hindu caste ideology. (Feldman and Fournier 1976: 448)

Related to this is the argument that rural elites do have some sort of connections to or affiliation with bureaucratic elites in Kathmandu. The original rural elites in Mahesh Khola were often Chhetri by caste, followed by some Brahmin. These are the two caste groups which, together with Thakuri, formed the ruling elites in Nepal until recently. Due to their connections to the central bureaucracy and the ruling elites in Kathmandu through class-caste affinity of some sort, what Bista calls, "afno machnne" (nepotism or patronage in general, see Bista, 1991), at least in part, they were able to ensure jobs for their youngsters. For example, Bhandari households, many of whom have jobs either in the Nepal Army or Nepal Police, have benefitted from their historic connection with Nepal's security forces. Similar 
is the case of some Brahmins, another "upper" caste group. Many of the Brahmin households from Siranchour, for example, have employment in the civil service, because they were closely linked with Rana through their priestly services. ${ }^{7}$ Kebar Bharati, one of my key-informants, says:

Those families who were smart at that time in maintaining their farm and at the same time ensuring [better] education for their children have excelled themselves well [now]. Perhaps not all of their children are ahead in terms of income necessarily, but they are quite ahead in their family haisiyat [pride and esteem].

-- Kebar Bharati, 55, a farmer and a community leader, Mahesh Khola

The household survey reveals that 24 of 61 sample households had such employment (including a pension of some kind) either in the civil service, army, police, or teaching in the local schools. The annual economic contribution from such employment (the estimated total amount sent home during 12 months preceding the survey) in the household income was almost equal to the combined incomes from both food crops and vegetables. For example, while the average income from a salary or pension was Rs 50,199 per household, it was Rs 57,802 from food crops and vegetables. The Chhetri, who hold relatively larger land plots, are also the ones with better access to government jobs, followed by Brahmin; both of whom form the so-called "upper" caste group. It reveals how caste and ethnic membership intersects with class position and creates social inequality in contemporary Mahesh Khola.

That many of the upper class households have managed to own urban residences in Kathmandu attests to this fact, an issue I shall elaborate shortly. Although having or not having farm land in the village still matters to some extent, having or not having jagir (some sort of employment in the formal sector) makes a lot more difference in the local social milieu: a clear marker of class position and 7. The Rana were the ruling dynasty in Nepal who under family autocracy ruled Nepal for 104 years until the popular uprising of 1950. The Brahmins of Siranchour are said to have been brought long ago from Gorkha to perform priestly jobs and were provided land grants, called kush birta, by some of these Rana (Lobanath Luintel, 65, Mahesh Khola). 


\section{6| Youba Raj Luintel}

modernisation. In the understanding of the local people employment as low as peon (messenger or office assistant) would give an income more than a big landowner is likely to earn from his or her total harvest.

To summarise, leaving Mahesh Khola (and by implication leaving the farm-based livelihood), and instead according emphasis in higher education and opting for jagir (employment) or byapar (trade) are some of the typical responses devised by the upper class households in Mahesh Khola, which have emerged now as a pattern. To me, this is a social manifestation of structural changes in the organisation of production brought about by capitalist expansion in the countryside. This has not only widened the gap between working class and upper class households, but has also distanced them spatially: an add on to the existing hierarchical form of inequality called caste.

This is a process I have called class divergence, a process that would lead to a social environment in which these households, in the longer run, would find it comfortable to leave the village and settle in Kathmandu permanently. It is for this reason that none of these households have found it worthwhile to invest any of their savings in their place of origin, because it becomes far more profitable to invest in Kathmandu, a booming metropolitan capital city. A majority of households in Mahesh Khola who have invested part of their saving in Kathmandu has done so mostly in land, followed by residential buildings or both, an issue that I discuss next in connection to residential and migratory practices identified in Mahesh Khola.

\subsection{Living in or leaving out? From dual residence to (self) displacement}

To Wallerstein, there are three major ways in which the arena of the household comes increasingly into the thrust of the capitalist worldeconomy and exhibits some major social disruptions. They are: (a) a steady pressure to break the link between the type of household organisation and its territoriality, and to diminish co-residentiality; (b) pressure on every individual household to engage in a mode of remuneration governed by "partial" wage labour, and (c) increasing stratification of labour on the basis of ethnicity, gender and other social group membership (Wallerstein , 1984, p. 19). 
In the case of Mahesh Khola, as the following discussion will reveal, the first two dynamics are quite relevant. Most of the households have split, and a household as a co-residential unit is no longer the predominant practice. Almost every household (particularly the working class households) have been exposed to a situation in which their survival depends very much on "partial" wage labour, be it in farm, nonfarm or of salaried-type, by at least one or more family member. Most importantly, there is social differentiation taking place, reflected in collective household strategies, which I argue is diverging along class lines. Now let me turn to the upper class households in relation to a process of (self) displacement from Mahesh Khola. The practice of dual residence (or what the villagers called dohoro basai) refers to a sort of multi-sited households embracing a host of practices in which a single household splits into two or more (sub)families (or individuals) living simultaneously in different places and optimising opportunities. Yet, they maintain the unit of the household by pooling various income sources, sharing family fortunes and misfortunes in common, and maintaining a shared identity under an elder household head. In Mahesh Khola, dual residence is a living arrangement in which some or all of the family members abandon the village in favour of settling in Kathmandu, in which one could have any immediate reason, such as getting a job, pursuing education or taking some sort of selfemployment (see Figure 1).

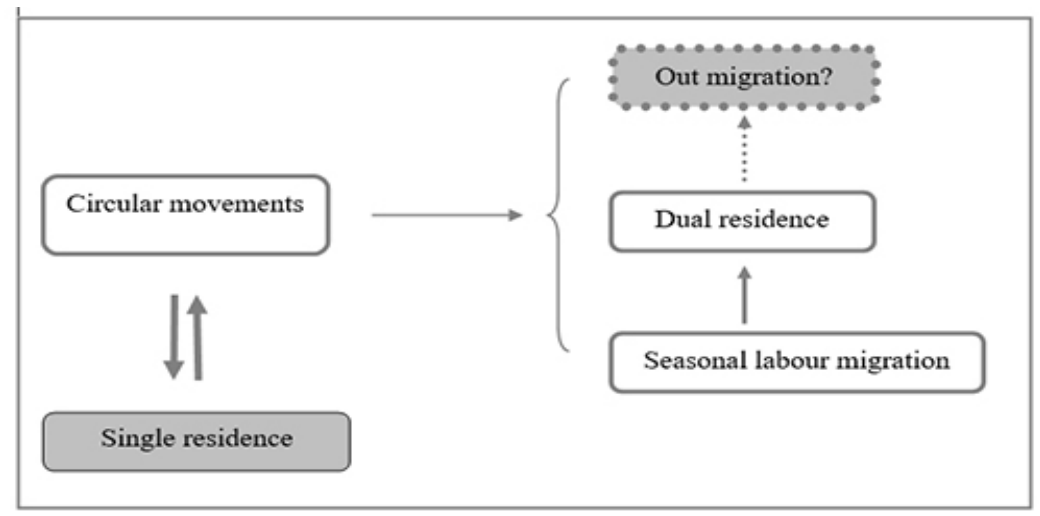

Figure 1: A schematic diagram of residence and migratory practices in Mahesh Khola 2007-08

(Source: Interviews and FGDs, Mahesh Khola, 2008) 


\section{8| Youba Raj Luintel}

What is important here is the intention of dual residence or (self) displacement, as Hugo (1982) argues. Such a family maintains its presence back in the village by keeping its estate, houses and other properties intact. Thus, their absence appears to be temporary, but in practice, very few of them would hope to return. Unlike the practice of dual residence, the term single residence (or what the villagers called, ekohoro basai) refers to the family practice in which household members live effectively under "a single roof" and share "a single kitchen," a conventional and mainstream practice in Nepal for rural households until very recently. If we imagine a continuum of single residence, on the one side and permanent out-migration, on the other, households under dual residence may fall somewhere in between but would tend to be closer to (or to be eventually resulted in) permanent out-migration. One of the essential features of such households is that not all of their family members would comfortably fit in the "single roof" and "single kitchen" criteria, a problematic that demands a redefinition of the very notion of household itself. Disintegration of a household such as this, as the case of Mahesh Khola reflects, needs to be understood as the inevitable outcome of the spread of capitalism at the household level (Wallerstein, 1984; Smith, Wallerstein et al., 1984b) because the act of abandoning the home is essentially driven by a pursuit of higher income, profit and a modern cosmopolitan living. Understandably, the base location of any individual household in this imagined continuum would be a combined manifestation of an individual household's demographic circumstances and economic priorities. But one common thread of argument that cross-cuts all social conditions is that dual residence represents a social reality of relatively privileged households, an issue I shall expand next.

\subsection{Dual residence as a manifestation of social privilege}

Drawing data from a supplementary thematic survey in which I covered 147 households, in this section, I focus on the practice of dual residence in Mahesh Khola. Of the 147 total households assessed under the thematic survey, the villagers identified 49 percent of households having their base of residence fully in the village (what is called "single residence" in this thesis), and the remaining 51 percent having some sort of dual residence (see Table 1). 
Dhaulagiri Journal of Sociology and Anthropology Vol. 9, $2015 \mid 39$

\section{Table 1: Percent distribution of households under single or dual residence by caste/ethnicity, Mahesh Khola, 2007-08}

\begin{tabular}{llll}
\hline & \multicolumn{2}{l}{ Distribution of houscholds } & Total \\
\cline { 2 - 3 } Caste/ethnic group & $\begin{array}{l}\text { Single residence } \\
(\%)\end{array}$ & $\begin{array}{l}\text { Dual residence } \\
(\%)\end{array}$ & $\begin{array}{l}\text { To } \\
(\%)\end{array}$ \\
\hline Brahmin ("upper" caste) & 15.0 & 17.0 & 32.0 \\
Chhetri ("upper" caste) & 17.0 & 14.0 & 31.0 \\
Sanyasi ("upper" caste) & 2.0 & 6.8 & 8.8 \\
\hline "Upper" caste subtotal & 34.0 & 38.1 & 72.1 \\
Ethnic groups subtotal & 12.2 & 11.6 & 23.8 \\
Dalit groups subtotal & 2.7 & 1.4 & 4.1 \\
\hline Total & 48.9 & 51.1 & 100.0 \\
& $(\mathrm{~N}=72)$ & $(\mathrm{N}=75)$ & $(\mathrm{N}=147)$ \\
\hline
\end{tabular}

Source: Thematic survey, Mahesh Khola, 2008

simultaneously. In actual practice in Mahesh Khola, dual residence means a split household: implying that while some family members live in the village maintaining their conventional and predominantly agrarian way of living, the rest of the members would migrate elsewhere (mostly to Kathmandu) for a particular reason, and would enjoy a cosmopolitan and modern life (see Liechty, 2008); yet they identify Mahesh Khola as their residential base (see Box 1).

Hence, there is a clear break between households and their place of origin. To Wallerstein this is a function of capitalism that breaks the link between household organisation and territoriality (1984). Although, there is a growing practice of family members leaving their home in search of jobs or self-employment, later accompanied by their children in quest of better education opportunities, the intensity of the process varies across settlements. In some settlements, namely Siranchour, Kukhurechour, and Bhangetar, for example, it is estimated that more than half of the total households have all (or some) of their family members in Kathmandu (see Box 1). 


\section{Box 1: Migration and dual residence in Mahesh Khola: Spme grounded observations}

In order to complement my discussion of the emerging process of (self) displacement and dual fesidence at the societal level, here I give some snapshots of individual cases that unpack the grounded accounts of this important process in contemporary Malhesh Khola. Although neither the household survey nor the keyinformant interviews or thematic survey found any case of permanent out-migration from Mahesh Khola in the


coumon phanomenon. Take the case of Siranchour. for example. It is predominantly a Brahnin settlement with a total 41 housaholds, a settlement ubere people had a relatively smaller amount of land (particularly, khef) compared to other settlements. But they were better educated. Edvcation enabled them to get employment in the formal sector in Kathmandu, a compensation for them having small amounts of land It was in Siranchour that the practice of dual fesidence was found to be the lighest of all.

When the parents took their children to Kathmandu for the sake of "better education" (Sharan Subedi. 40, local teacher and farmet, Mahesh Khola), the children's mother had to follow them as the carer. Hence, a commonly observed phenomenon in Surachour has been that, whilst many of the people in their 308 or 408 were living in Kathmandu, followed by their spouses and children, it was mostly their older parents who were left behind in the village. During my field visits, I found several such houses and some of which were completely empty and locked, and the lands rented-out to someone else. Similar was the case of Bhangetar, a settlement with 18 households comprised of serven "upper" caste and 11 Danuwar (an ethric group who had always been subservient to their landowners) bouseholds. While the "upper" caste households historically bad been landlords, monevenders and providers of wase work, the Danurwar were near-landless, lowly educated and largely marginalised.

In this settlement, it was very hard to find any younger and or adult persons in their 308 or 408, notably so among "upper" caste households and to some extent among Danuwar. Most of them had gone to Kathmandu in connection with their education, employment or trade. Some of the Danuwar had gone to Kathmandu even for menial kinds of casual work. Very recently, a few of them had gone oreeseas as part of labour migration. Hence, Bhangeter was the second village where dual residence was found to be the highest. Settlements like Mabantagena and Bhandarigan, too, exhibited a similar pattern and had similar practices of dual residence but to a lesser extent.

With the rare exception of one or two, there are no instances of any such families returning to the village. ${ }^{8}$ Lobanath Luintel, one of my key-informants, is often exemplified by common villagers as one of the successful persons in managing the transition to urban life in Kathmandu. Part of my conversation with him on issues of the

8. These were the villages where the household falling within the sample were found to be untraceable and I had to choose the next one immediate in the list, but still unsuccessfully. 
practice of dual residence and its long-term likely impact on farming back in the village, addresses this issue:

That [doing farming in the village] is gone now. It is [just] up to our generation that we are not leaving our land fallow. I often go back to village to take care of everything. I do so because I've got a certain inclination to rural life and I love it. Now, these people [implying to the younger generations]! They would not bother it... Once I become unable, this [rural-urban connections] will end in my sense, it's as simple as that. My sons do not know who does what back in village. People with that body shape! People who cannot even twist and turn their bodies, how can they cultivate lands? Its just up to my generation, yes. After that people will even forget how difficult it was for us who entered into Kathmandu without leaving the village completely.

-- Lobanath Luintel, 65, a retired university employee who lives in Kathmandu still maintaining his land and houses in Mahesh Khola

As a result, there has been an increasing tension related to the management of their property back in village, as most of them have still maintained it. ${ }^{9}$ Thus, significant proportion of land and houses are under-utilized.

One of the central tenets of this discussion is that dual residence is a social mechanism that facilitates a process of (self) displacement, and manifests a process of social differentiation of more horizontal or spatial kind. As Table 1 shows, while more than half of the "upper" caste households have maintained dual residence, only one-third of Dalit household could do so. The ethnic households are slightly behind their "upper" caste counterparts but are far ahead of Dalit households: a typical reflection of the social structure and inequality in Mahesh Khola as elsewhere in Nepal. Hence, it gives me a reasonable grounds to argue that while the residence practice primarily relates to household survival strategies; it also credible that it reflects caste/ethnic disparity among the households: higher caste

9. While the new generation wants to sell all the land immediately, the older generation would prefer not to sell. So, there is an inter-generational conflict going on as to whether to dispose of all of the land in the village immediately or to keep hold of it for some time. 
households are more likely to migrate (or to have dual residence of some sort) than their Dalit counterparts.

What are the characteristics of households maintaining dual residence? Do they share a similar class position? Table 2 allows us to scrutinise these households further to identify whether any class disparity exists with regard to residence practice. Of the three broader categories of labour regimes identified in the table, two groups of households (hiring wage labourers, and self-reliant on family labour) exhibit some commonality with respect to their residence practice. The shares of households in single and dual residence are somehow comparable, with dual residence slightly exceeding single residence.

Table 2: Percent distribution of households under single or dual residence by household labour regime, Mahesh Khola, 2007-08

\begin{tabular}{|c|c|c|c|}
\hline \multirow[b]{2}{*}{ Houshobld labuit rogitie } & \multicolumn{2}{|c|}{ Distribution of luoushodids } & \multirow[b]{2}{*}{$\begin{array}{l}\text { Total } \\
(\%)\end{array}$} \\
\hline & $\begin{array}{l}\text { Single residenee } \\
(\%)\end{array}$ & $\begin{array}{l}\text { Dud resdence } \\
(\%)\end{array}$ & \\
\hline Doing wage labour & 13.6 & 9.5 & 23.1 \\
\hline Hiring vage labour & 24.5 & 25.2 & 49.7 \\
\hline Self reliant on fanily labout & 109 & 12.2 & 23,1 \\
\hline Inapplicablet & 0.0 & 4.1 & 4.1 \\
\hline \multirow[t]{2}{*}{ Total } & 489 & $\$ 1,1$ & 1000 \\
\hline & $(\mathrm{N}=72)$ & $(\mathrm{N}=75)$ & $(N=147)$ \\
\hline
\end{tabular}

Soure: Thematic suncy, Mahesh Khola, 2008

$\uparrow$ Families which live fully in Kathmandu and thus have sold or rented out all of their farm land in Mahesh Khola are categorised as "inapplicable" in the discussion of labour regime

Households deriving their livelihoods from wage labour clearly stand out from the rest because single residence outnumbers those having dual residence in this subsection. Those having single residence represent the poorest of the poor segment in Mahesh Khola (in 
terms of both asset-ownership and level of income) and embody the working class. In other words, of those households which did wage labour ( 23 percent of the total, $\mathrm{N}=34$ out of 147 households) only a little less than half of them ( 9.5 percent of the total, $N=14$ of 147 households) had been able to maintain dual residence (Table 2).

This allows me to conclude that, like caste and ethnic categories, the labour regime of the household has the potential to reveal class disparity in Mahesh Khola. For example, those households which have all of their family members at home generally have a lower economic status, for such households often miss out an effective source of cash income. The female-headed households, households headed by a widow/widower or terminally sick person, and the very poor and near-landless households will not be able to deploy any of its members outside the home. Households such as these are found to be maintaining a low profile in the village and remaining mostly invisible in the community. Hence, feminists' insistence that the study of household strategy needs a gendered analysis appears to be relevant here (Wong, 1984; Folbre, 1986; Mallon, 1986; Bonney, 1988; Kandiyoti, 1988; Agarwal, 1997; Laurie, 1997; Wolf ,1997).

Among those maintaining dual residence, the ones who have not been able to buy land and buildings in Kathmandu suffer from uncertainties about whether they would be able to settle there, because the price of land in the capital city is rapidly increasing. Some of these families do not want to sell all their property back in Mahesh Khola because of uncertainties looming in their business or fear of social and emotional costs of an old age life in Kathmandu. Part of the problem also relates to the issue that, except for a few newly built road corridors, the price of land has remained static and land transactions have slackened in Mahesh Khola because there are more people willing to sell than to buy. Because these households have not been able to sell their property completely, they have no option but to maintain dual residence to some degree.

\section{6 (Self) displacement and the transfer of rural surplus}

The previous discussion on the intra-class divergence of the working class and the upper class showed that it eventually resulted in a social situation of dual residence, and even (self) displacement of (mainly) the upper class households. It also hinted a number of social 


\section{4| Youba Raj Luintel}

disruptions that it brought in the local context of Mahesh Khola. As a logical extension of the same discussion an attempt has been made below to problematise the issues of surplus creation and its investment. In connection to investment, some core issues need to be highlighted at the onset. What has been observed broadly in Mahesh Khola is that: a) no investment is made in the village itself and all the surplus has been expropriated to Kathmandu; (b) investment in urban residences by purchasing residential land and/or houses is the single most important way in which almost all households having dual residence have invested their surplus. To generalise it, what seems clear is that the surplus that Mahesh Khola had generated over the years (mainly from vegetable farming) and which brought it in the limelight of development discussion in Nepal, has been appropriated to Kathmandu.

Feldman and Fournier (1976) argue that an analysis of the process of surplus production, expropriation and realisation is key to the understanding of both of the development process and the forces which are leading to transformation arising out of relations of production, as this article has highlighted so far. The problem is that documenting the actual size of the surplus (thereby, surplus making and potential investment) is a challenging job, which could only be partially achieved. Akram-Lodhi in his study of the realisation of the exchange value of wheat in "real" markets in Northern Pakistan acknowledges this fact when he writes, "[w] hile the control of the means of production in a partly commoditised economy remains reasonably straightforward to substantiate, understanding the extraction of surplus is more complex" (2001, p. 84). ${ }^{10}$ While analysing the root cause of development of underdevelopment in Nepal in the context of the outflow of capital from Nepal to India, Mishra argues that "[t]he outflow of capital is very difficult to document - mostly because it is deliberately hidden or camouflaged" (1987, p. 124), and Deere and de Janvry (1979) suggest various ways capital is out-flowed.

I found it equally daunting even in the case of village level analysis, 10. He instead cites Deere and de Janvry (1979) who identify seven channels by which the surplus generated by a peasant household might be appropriated. These include indirect channels consisting of rent in kind, rent in cash, rent in labour services, and extraction of surplus value together with direct channels embracing usury, taxation and terms of trade. 


\section{Dhaulagiri Journal of Sociology and Anthropology Vol. 9, 2015 |45}

for it needs longer field stays, more participatory and ethnographic methods, and a higher level of rapport with the people. Beside, this is a very sensitive issue for a household which nobody likes to disclose fully. For this reason, it is not my aim to give the actual size of saving and investment, as my research questions do not require that, rather I aim to show how the locally investible surplus of the agrarian and peripheral rural setting is being transferred to the non-agrarian and urban core (rather say, metropolitan centre); thus, leaving the countryside underinvested. ${ }^{11}$

Of the 147 households covered in the thematic survey, 75 households were involved in the practice of dual residence, of which the villagers had a fairly good knowledge of 73 households only. Thus, identifying 73 households as potential investors in Kathmandu, Tables 3 and 4 present their distribution on the basis of whether they had any investment, disaggregated by caste/ethnic identity and labour regime. As only two investment fronts (viz. residential land, and both land and building) were frequently reported during the thematic survey, Tables 3 and 4 disaggregate them with households having dual residence but not yet having any investment. Broadly speaking, it seems that 61.7 percent of the households having dual residence made "some investment" in urban residences in Kathmandu, followed by 38 percent as yet having "no investment."

As Table 3 makes it clear, while about 55 percent of households invested in land and building(s) (ghar and ghaderi) in Kathmandu, another 7 percent managed to buy plot(s) of residential land (ghaderi) only. This finding gives us grounds to argue that there has been a rapidly increasing trend of investment outside Mahesh Khola, and as the observation reveals, this is growing over the years.

11. The data on household investment, used in this context, are derived from the hearsay accounts of third parties, a couple of key-informants in each of the six settlements who were relatively knowledgeable about their respective settlements. Because hearsay accounts can tell us only (or mostly) what is visible in the local context, they can never be fully verified, because household economy in general and saving and investment in particular are confidential household issues. A couple of practical reasons are at work here. First, hiding information on savings and investment may avoid tax. Second, it can be protected from any potential family disputes, especially at the time of property division and inheritance. Third, it also protects the family from the potential envy of others. 
Hence buying a piece of land and erecting a building in Kathmandu has become an upper class ethos in rural Nepal. A similar trend was observed during the nineteenth century Nepal.

\section{Table 3: Percent distribution of households having dual residence with or without investment in Kathmandu by caste/ethnicity, Mahesh Khola, 2007-08}

\begin{tabular}{|c|c|c|c|c|}
\hline \multirow[b]{2}{*}{ Castelethnic group } & \multicolumn{3}{|c|}{ Investnent portfolio } & \multirow[b]{2}{*}{$\begin{array}{l}\text { Total } \\
(\%)\end{array}$} \\
\hline & $\begin{array}{l}\text { No } \\
\text { Itivesthent } \\
(\%)\end{array}$ & $\begin{array}{l}\text { On land oily } \\
(\%)\end{array}$ & $\begin{array}{l}\text { On land and } \\
\text { buildisg both } \\
(\%)\end{array}$ & \\
\hline Brahmin & 11.0 & 27 & 192 & 329 \\
\hline Chotiti & 1.4 & 0.0 & 27,4 & 28.8 \\
\hline Sanyas่ & 4.1 & 1.4 & 8.2 & 13.7 \\
\hline "Lpper" caste subtotal & 164 & 41 & 94.8 & 753 \\
\hline Ethric groups subtotal & 20.5 & 14 & 0.0 & 219 \\
\hline Dalit groups subtotal & 1.4 & 1.4 & 0.0 & 2.8 \\
\hline Totil & $\begin{array}{l}383 \\
\mathrm{~N}=28\end{array}$ & $\begin{array}{l}69 \\
\mathrm{~N}=9\end{array}$ & $\begin{array}{l}34.8 \\
N=40)\end{array}$ & $\begin{array}{l}1000 \\
(\mathrm{~N}=73) \dagger\end{array}$ \\
\hline
\end{tabular}

Source: Thematic survey, Mahesh Khola, 2008

$\dagger$ Two cases have been deleted in this table because their labour status was unclear to the villagers. While one of the household belonged to the "upper" caste and was engaged in wage work, the other belonged to the ethnic group.

M. C. Regmi in his authoratitative account of the peasants and landlords in the nineteenth century Nepal writes:

$[t]$ he deleterious effect of...exploitation on the economic condition of the peasant might have been offset in some measure had the landowning elite invested at least a part of their income for raising the productivity of agriculture. There is, however, no evidence [of any productive investment of that kind. Instead] Construction of houses appears to have been one way in which the landowning elite of Kathmandu used their income. (also see Oldfield, 1974 [1880]; Regmi, 1978b) 
I argue that this is a clear indication of the outflow of surplus generated in the countryside in an agrarian setting. Table 3 also highlights some daunting facts of widening social inequality and disparity developing over the years in Mahesh Khola. For example, of the 75 percent "upper" caste households having dual residence, 59 percent had invested in Kathmandu. On the contrary, only 1.4 percent of ethnic households (out of their 22 percent representation in dual residence practice) as yet had "some investment."

\section{Table 4: Percent distribution of households having dual residence with or without investment in Kathmandu by household labour regime, Mahesh Khola, 2007-08}

\begin{tabular}{|c|c|c|c|c|}
\hline \multirow[b]{2}{*}{$\begin{array}{l}\text { Houschold } \\
\text { regime }\end{array}$} & \multirow{2}{*}{$\begin{array}{l}\text { No } \\
\text { Investment } \\
(\%)\end{array}$} & \multicolumn{2}{|c|}{ Investment portfolio } & \multirow[b]{2}{*}{$\begin{array}{l}\text { Total } \\
(\%)\end{array}$} \\
\hline & & $\begin{array}{l}\text { On land only } \\
(\%)\end{array}$ & $\begin{array}{l}\text { On land and } \\
\text { building both } \\
(\%)\end{array}$ & \\
\hline Hiring wage labour & 12.4 & 4.1 & 34.2 & 50.7 \\
\hline Self reliant & 6.8 & 1.4 & 16.4 & 24.7 \\
\hline Doing wage labour & 16.4 & 1.4 & 0.0 & 17.8 \\
\hline Inapplicable $\dagger$ & 2.7 & 0.0 & 4.1 & 6.8 \\
\hline Total & $\begin{array}{l}38.3 \\
(\mathrm{~N}=28)\end{array}$ & $\begin{array}{l}6.9 \\
(\mathrm{~N}=5)\end{array}$ & $\begin{array}{l}54.8 \\
(\mathrm{~N}=40)\end{array}$ & $\begin{array}{l}100.0 \\
(\mathrm{~N}=73)+t\end{array}$ \\
\hline
\end{tabular}

Source: Thematic survey, Mahesh Khola, 2008

$\uparrow$ Families which lived fully in Kathmandu and thus had sold or rented out all of their farm land in Mahesh Khola are categorised as "inapplicable" in the discussion of labour regime.

$\dagger$ As with Table 3, two cases have been deleted in this table because their labour status was unclear.

With respect to the household labour regime (see Table 4), those "doing wage labour" (the proper working class households) stood out quite clearly from the rest, as only 1.4 percent of them (out of 17.8 percent representation in dual residence) had managed to buy land, none of them, however, had bought both land and buildings. On the contrary, more than two-thirds of those who hired wage workers (the proper upper class) had invested in land (4.1 percent) 


\section{8| Youba Raj Luintel}

and both land and buildings ( 34.2 percent). In this way, a very clear disparity along class lines is visible in Mahesh Khola with regards to the group of households making investments in urban residences beyond the village.

Although the story of (self) displacement of the upper class households from Mahesh Khola might give an impression that they are the losers in the changing class formation in Mahesh Khola, in reality that is not the case. Their displacement, I argue, is centrally associated with the process of expropriation of savings generated in the countryside. The eventual social implications of this new and emerging dynamic is that, (on top of the existing inequality of class, perpetuated in the form of caste/ethnicity and disparities in land holdings, which was principally vertical in its nature), their displacement has created a new form of disparity (which is more horizontal in its formation) between the peripheral countryside and Kathmandu as the metropolitan centre.

\section{Conclusion}

This article has focussed on household strategy in Mahesh Khola in the context of the increasing market expansion in their lives and livelihoods. Drawing data from a household survey and interviews, it highlighted different methods of coping strategy the upper class households have devised during the last decade or more. My interest in household strategies relate to recent social science acknowledgement that "households are not the helpless puppet of structural forces" (Wallace, 1993, p. 95), such as the capitalist market, and the recognition that they do strategise themselves in the changing political economic circumstances by negotiation and resistance with the larger structural processes shaping their lives.

This article has shown that unlike the working class households, the story of the upper class is quite different. Their earlier investments in education for the children, together with their class-caste connections with the bureaucracy in Kathmandu, had already enabled them to get paid employment there. This, together with the profits they could draw from trading in vegetables, drew them more to Kathmandu. The village became progressively a more awkward place for them to live because they could not optimise the gain from their land in 
the context of growing labour scarcity coupled with their dwindling political-economic influence as the rural elite, a privilege they had enjoyed before.

Hence, their story is the story of eventual (self) displacement from the village. By renting-out their land (even in deteriorating terms of trade, such as bikase thekka) to the working class households, ${ }^{12}$ they have now turned to trade, education and employment, and have starting fairly new nonfarm based livelihoods in Kathmandu. This, I argue, is a process of (self) displacement from the village, but paradoxically they are still hovering between village and Kathmandu in a situation I called dual residence. These back and forth links, that the upper class households have maintained, have become a social reality to them that allows them to maintain networks and social relations through with they can draw more profit from their trade involvement in the Kathmandu. But at the same time, the social dynamics of back and forth linkages amidst a situation of eventual (self) displacement represent a social reality that is characterised predominantly by social instability, disruption and hardship, issues that deserve fully-fledged research in the future.

What implications does this entail to larger social change in the longer term? First, this article has shown that no investment is made in the village itself. Despite whatever surplus (may) have been generated there all the savings have been transferred to Kathmandu. Second, the surplus transferred to Kathmandu has been exclusively invested in the sector of real estate and urban residences, both of which represent unproductive investments. This implies that the sector where the surplus was generated (such as Mahesh Khola or the rural agricultural sector as a whole) is affected by an increasing problem of chronic disinvestment, which I argue is a case that represents underdevelopment as a part of the result of capitalist encroachment.

\section{References}

Agarwal, B. (1997). "'Bargaining' and gender relations: Within and 12. In fact, many such families wanted to sell their land altogether, so as to come out of this problem completely. 
beyond the household," Feminist Economics, 3(1), pp. 1-15.

Akram-Lodhi, A. H. (2001). "'We earn only for you': Peasants and 'real' markets in Northern Pakistan," Capital and Class, 25(2), pp. 79-108.

Bista, D. B. (1991). Fatalism and Development: Nepal's Struggle for Modernization, Calcutta, Orient Longman.

Bonney, N. (1988). "Gender, household and social class," British Journal of Sociology, 39(1), pp. 28-46.

CBS (2005). Poverty Trends in Nepal (1995-96 and 2003-04), Kathmandu, Central Bureau of Statistics, His Majesty's Government of Nepal.

CBS (2006a). Nepal Living Standard Survey (1995-96 and 2003-04) Analysis of Panel Households, Kathmandu, Central Bureau of Statistics, His Majesty's Government of Nepal.

CBS (2006b). Resilience Amidst Conflict: An Assessment of Poverty in Nepal, 1995-96 and 2003-04, Kathmandu, Central Bureau of Statistics, Government of Nepal with support from The World Bank, DFID, and the Asian Development Bank.

Crow, G. (1989). "The use of the concept of 'strategy' in recent sociological literature," Sociology, 23(1), pp. 1-24.

Davies, S. (1993). "Are coping strategies a cop-out?" IDS Bulletin, 24(4), pp. 60-72.

Deere, C. D. and de Janvry, A (1979) 'An empirical approach to the analysis of peasants,' American Journal of Agricultural Economics, 61(4), pp. 601-611.

DFID and WB (2006). Unequal Citizens: Gender, Caste and Ethnic Exclusion in Nepal, Kathmandu, Department for International Development (DFID) and the World Bank (WB).

Feldman, D. and A. Fournier(1976). "Social relations and agricultural production in Nepal's Terai," Journal of Peasant Studies, 3(4), pp. 447-464.

Folbre, N. (1986). "Hearts and spades: Paradigms of household economics," World Development, 14(2), pp. 245-255. 
Hugo, G. J. (1982). "Circular migration in Indonesia," Population and Development Review, 8(1), pp. 59-83.

Kandiyoti, D. (1988). "Bargaining with patriarchy," Gender and Society, 2(3), pp. 274-290.

Laurie, N. (1997). "Negotiating femininity: Women and representation in emergency employment in Peru," Gender, Place and Culture, 4(2), pp. 235-251.

Liechty, M. (2008). Suitably Modern: Making Middle-Class Culture in Kathmandu, Kathmandu, Martin Chautari (originally published by Princeton University Press in 2002).

Mallon, F. E. (1986). "Gender and class in the transition to capitalism: Household and mode of production in central Peru," Latin American Perspectives, 13(1), pp. 147-174.

Mishra, C. (1987). "Development and underdevelopment: A preliminary sociological perspective," Occasional Papers in Sociology and Anthropology, 1, pp. 105-135.

Morgan, D. H. J. (1989). "Strategies and sociologists: A comment on Crow," Sociology, 232(1), pp. 25-29.

Oldfield, H. A. (1974 [1880]). Sketches from Nepal, Delhi, Cosmo Publications.

Panini, M. N. (1996). "The political economy of caste," Caste: Its Twentieth Century Avatar, M. N. Srinivas. New Delhi, Penguin Books, pp. 28-68.

Regmi, M. C. (1978b). Thatched Huts and Stucco Palaces: Peasants and Landlords in 19th Century Nepal, Delhi, Adroit Publishers.

Sen, A. K. (1990). "Gender and cooperative conflicts," Persistent Inequalities, I. Tinker (ed.). New York, Oxford University Press, pp. 123-149.

Smith, J., I. Wallerstein, et al. (1984b). "Introduction," Households and the World-Economy, J. Smith, I. Wallerstein and H.D. Evers (eds.). Beverly Hills, Sage Publications, pp. 7-13.

Wallace, C. (1993). "Reflections on the concept of 'strategy,"' Debates in Sociology, D. Morgan and L. Stanley (eds.). 
Manchester, Manchester University Press, pp. 94-117.

Wallace, C. (2002). "Household strategies: Their conceptual relevance and analytical scope in social research," Sociology, 36(2), pp. 275-292.

Wallerstein, I. (1984). "Household structures and labour-force formation in the capitalist world-economy," Households and the World-Economy. J. Smith, I. Wallerstein and H. D. Evers (eds.). Beverly Hills, Sage Publications, pp. 17-22.

Warde, A. (1990). "Household work strategies and forms of labour: Conceptual and empirical issues," Work, Employment and Society, 4(4), pp. 495-515.

Wolf, D. L. (1997). "Daughters, decisions and domination: An empirical and conceptual critique of household strategies," The Women, Gender and Development Reader, L. Duggan, L. Nisonoff and N. Wiegersma (eds.). London, Zed Books Ltd., pp. 118-132.

Wong, D. (1984). "The limits of using the household as a unit of analysis," Households and the World-Economy, J. Smith, I. Wallerstein and H. D. Evers (eds.). Beverly Hills, Sage Publications, pp. 56-63. 